\title{
Secondary syphilis: The great imitator can't be forgotten
}

\author{
Clarissa Prieto Herman Reinehr ${ }^{1 *}$, Célia luiza Petersen Vitello Kalil ${ }^{2}$, Vinícius Prieto Herman Reinehr ${ }^{3}$ \\ ${ }^{1} \mathrm{MD}$, Dermatologist, Member of the Brazilian Society of Dermatology, Master's Student at the Universidade Federal do Rio Grande do Sul, Porto Alegre, RS, Brazil \\ ${ }^{2}$ Dermatologist, Member of the Brazilian Society of Dermatology, Porto Alegre, RS, Brazil \\ ${ }^{3} \mathrm{MD}$, General Practitioner, Porto Alegre, RS, Brazil
}

Study conducted at Clínica Dermatológica

Célia Kalil, Porto Alegre, RS, Brazil

Article received: $11 / 7 / 2016$ Accepted for publication: $12 / 4 / 2016$

*Correspondence: Address: Rua Félix da Cunha, 1.009, conj. 401

Porto Alegre, RS - Brazil

Postal code: 90570-001

cla.reinehr@gmail.com

http://dx.doi.org/10.1590/1806-9282.63.06.481

\section{SUMMARY}

Syphilis is an infection caused by Treponema pallidum, mainly transmitted by sexual contact. Since 2001, primary and secondary syphilis rates started to rise, with an epidemic resurgence. The authors describe an exuberant case of secondary syphilis, presenting with annular and lichen planus-like lesions, as well as one mucocutaneous lesion. Physicians must be aware of syphilis in daily practice, since the vast spectrum of its cutaneous manifestations is rising worldwide.

Keywords: cutaneous syphilis, sexually transmitted disease, benzathine penicillin G, Treponema pallidum.

\section{INTRODUCTION}

Syphilis is an infection caused by Treponema pallidum, a spirochete bacterium transmitted mostly by sexual contact. Spirochetes penetrate skin or mucosa in areas of microtrauma and disseminate systemically within 24 hours. ${ }^{1}$

The incidence of syphilis started to rise again in 2001, with epidemic resurgence especially among men who have sex with men and HIV-infected patients. ${ }^{2}$ More specifically, the incidence of syphilis has tripled in the last 10 years. ${ }^{3}$ The authors describe an exuberant case of secondary syphilis.

\section{Case report}

A previously healthy 63-year-old man presented with cutaneous asymptomatic lesions that appeared approximately three months before, first on the hands and wrists, and later affecting feet, thighs and lips. During the clinical examination, sharply demarcated hyperkeratotic, violaceous scaly plaques on his hands and feet, including annular and well-circumscribed lesions on the palms and soles were observed (Figure 1); also, the patient showed a papule located at the right angle of the upper lip (Figure 2). First hypotheses included lichen planus and secondary syphilis. He denied previous genital ulceration, but reported unprotected sex in the past. Laboratory tests revealed a venereal disease research laboratory test (VDRL) titer of 1:32 (normal value < 1:2) and positive tests for syphilis-specific IgM and IgG antibodies. Serology was negative for human immunodeficiency virus and hepatitis B and C. A diagnosis of secondary syphilis was con- firmed and the patient was treated with three weekly intramuscular injections of benzathine penicillin G $2.4 \times 10^{6}$ IU. ${ }^{4}$ The patient was advised to contact his sexual partners so that they could seek medical evaluation. One month after treatment, the lesions resolved (Figure 3).

\section{Discussion}

Secondary syphilis, the most florid stage of the disease, called "the great imitator," has a variety of cutaneous manifestations. ${ }^{5}$ The onset of secondary syphilis varies but typically occurs two to eight weeks after the disappearance of the primary chancre. This stage can present with systemic symptoms and painless generalized adenopathy. If left untreated, secondary syphilis tends to progress to a latent stage, but clinical manifestations can recur for up to five years if not treated. ${ }^{1}$

The first cutaneous manifestation of secondary syphilis is a macular nonpruritic rash, composed of small and well-defined erythematous and/or hyperpigmented lesions (roseola syphilitica) that spontaneously resolve in 20 to 40 days. ${ }^{6}$ Some time after that, the classic exanthema of secondary syphilis occurs: a diffuse nonpruritic maculopapular rash that frequently involves palms, soles and scrotum. Variants of classic secondary syphilis rash include annular, pustular, nodular, nodulo-ulcerative, berry-like, corymbiform, photosensitive systemic lupus erythematosus-like, lues maligna, leukoderma and chancriform presentations. ${ }^{6}$

The classic maculopapular rash can mimic lichen planus, with violaceous flat-topped papules on the wrists, lower legs and acral sites, as observed in our case. ${ }^{7}$ The 


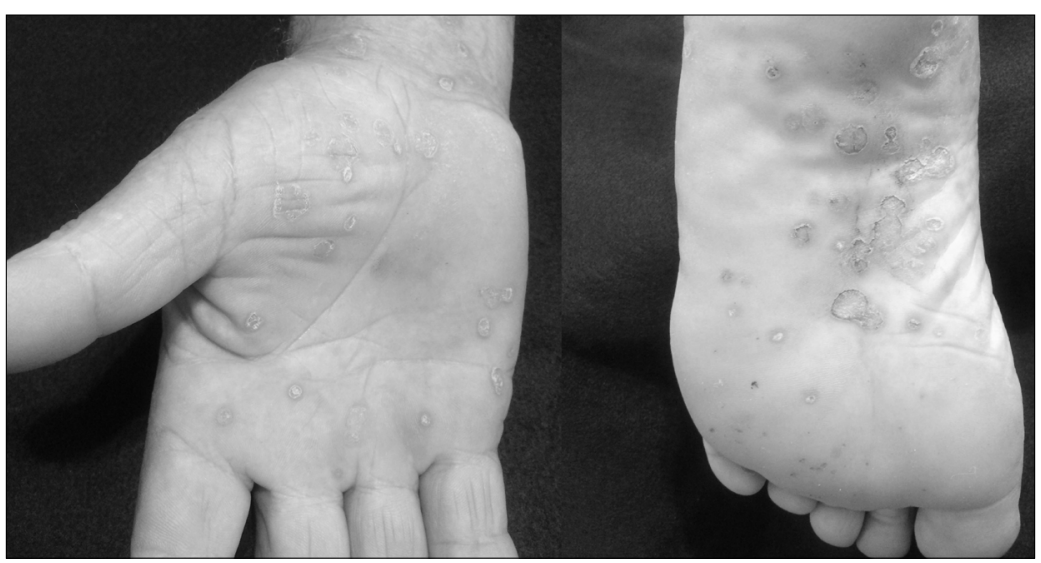

FIGURE 1 Sharply demarcated hyperkeratotic, violaceous, scaly plaques on the hands and feet, including annular and well-circumscribed lesions on the palms and soles.

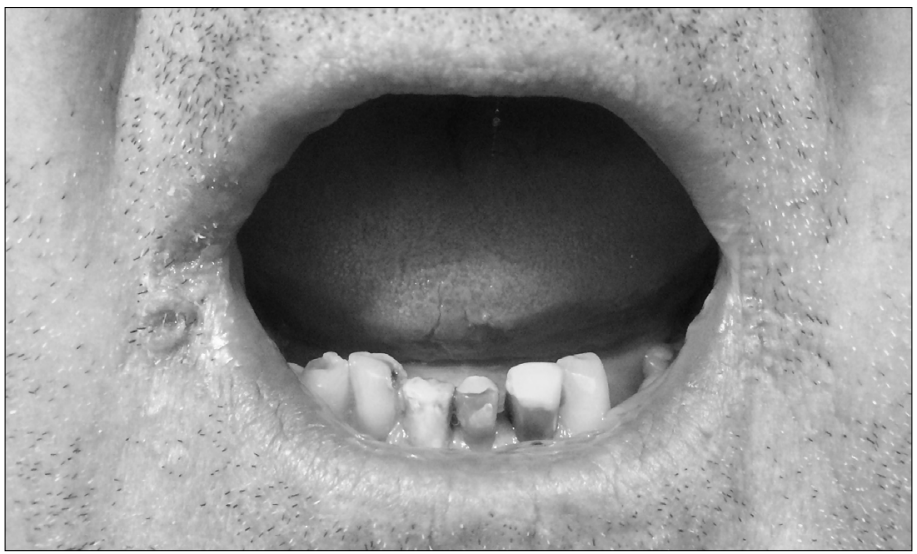

FIGURE 2 Papule located at the right angle of the upper lip.

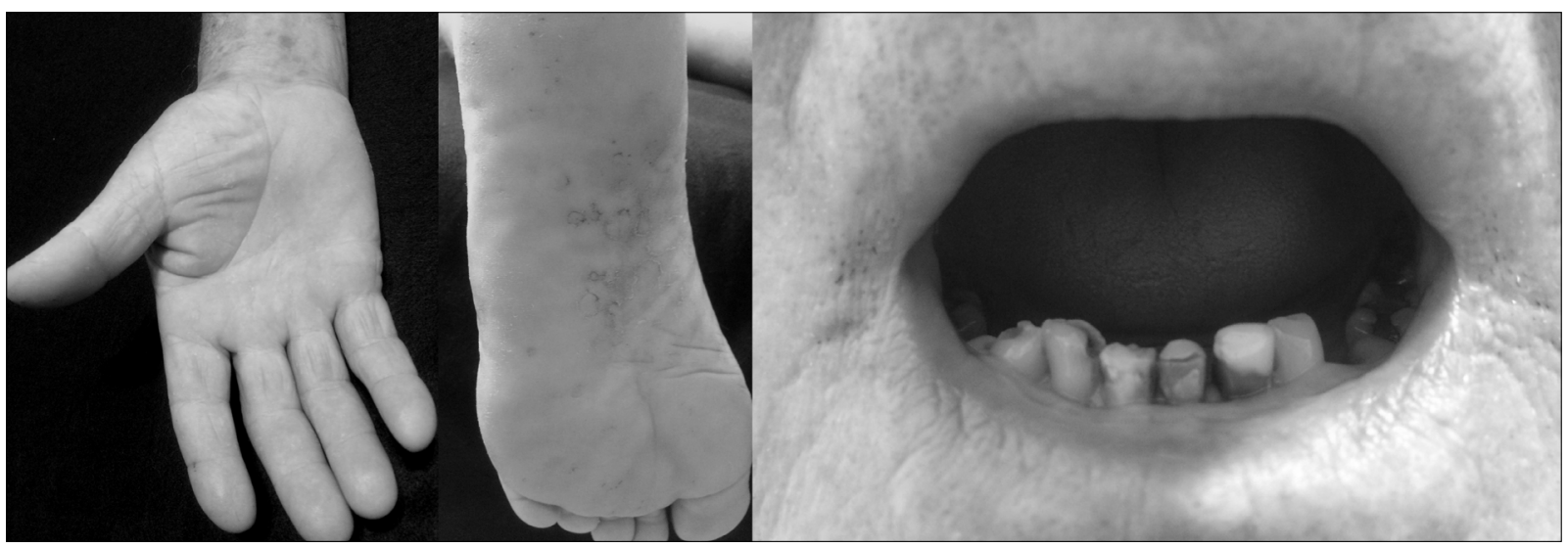

FIGURE 3 Regression of lesions one month after treatment. 
main difference between these two diseases is that syphilitic lesions are usually nonpruritic and they tend to affect palms and soles. ${ }^{5}$

Our patient also had annular lesions with well-defined scaly borders on the palms and soles, a well-described feature of secondary syphilis; ${ }^{6}$ some of these lesions were thicker than others and also displayed a violaceous hue. This finding should remind dermatologists of a variety of conditions in the differential diagnosis, including lichen planus, subacute lupus erythematosus, sarcoidosis, mycobacterial infection, granuloma annulare, erythema annulare centrifugum and dermatophytosis. ${ }^{6}$

Mucous plaques and split papules at the angle of the lips are other findings of secondary syphilis; the latter was observed in our patient. ${ }^{1}$

Secondary syphilis diagnosis in daily practice includes clinical suspicion due to the presence of characteristic skin and mucous lesions and confirmation by serologic tests that measure nontreponemal and treponemal antigens. ${ }^{8}$ Treatment of choice remains benzathine penicillin G, and quantitative titers of VDRL are used to verify treatment success together with the clearance of lesions. ${ }^{9}$ In addition, sexual partners must be examined and tested for syphilis. ${ }^{3}$

To conclude, physicians must be aware of syphilis: the spectrum of cutaneous manifestations is vast and rates of this infection keep rising worldwide.

\section{Conflict of interest}

The authors declare no conflict of interest.

\section{Resumo}

Sífilis secundária: a grande imitadora não pode ser esquecida
A sífilis é uma infecção causada pela espiroqueta Treponema pallidum, transmitida principalmente por contato sexual. Desde 2001, houve o ressurgimento dessa epidemia, com aumento das taxas de sífilis primária e secundária. Os autores descrevem um caso exuberante de sífilis secundária apresentando lesões cutâneas anulares e lesões que lembram líquen plano, além de uma lesão mucocutânea. Médicos de todas as especialidades devem estar cientes das diversas apresentações de sífilis: o vasto espectro de manifestações cutâneas da sífilis secundária e as crescentes taxas dessa patologia representam um desafio.

Palavras-chave: sífilis cutânea, doenças sexualmente transmissíveis, penicilina G benzatina, Treponema pallidum.

\section{References}

1. Cohen SE, Klausner JD, Engelman J, Philip S. Syphilis in the Modern Era. Infect Dis Clin North Am. 2013; 27(4):705-22.

2. Buchacz K, Klausner JD, Kerndt PR, Shouse RL, Onorato I, McElroy PD, et al. HIV incidence among men diagnosed with early syphilis in Atlanta, San Francisco, and Los Angeles, 2004 to 2005. J Acquir Immune Defic Syndr. 2008; 47(2):234-40

3. Morales-Múnera EC, Fuentes-Finkelstein PA, Vall Mayans M. Update on the diagnosis and treatment of syphilis. Dermosifiliogr minutes. 2015; 106:68-9.

4. 2015 STD (Sexually Transmitted Diseases) Treatment Guidelines [Internet] Available from: http://www.cdc.gov/std/tg2015/syphilis.htm.

5. Ivars Lleó M, Clavo Escribano P, Menéndez Prieto B. Manifestaciones cutáneas atipícas en la sífilis. Actas Dermo-Sifiliográficas. 2016; 107(4):275-83.

6. Balagula Y, Mattei PL, Wisco OJ, Erdag G, Chien AL. The great imitator revisited: the spectrum of atypical cutaneous manifestations of secondary syphilis. Int J Dermatol. 2014; 53(12):1434-41.

7. Nazzaro G, Boneschi V, Coggi A, Gianotti R. Syphilis with a lichen planuslike pattern (hypertrophic syphilis): Letter to the Editor. J Cutan Pathol. 2012; 39(8):805-7.

8. Farhi D, Dupin N. Origins of syphilis and management in the immunocompetent patient: facts and controversies. Clin Dermatol. 2010; 28(5):533-8.

9. Morales-Múnera CE, Fuentes-Finkelstein PA, Vall Mayans M. Update on the diagnosis and treatment of syphilis. Actas Dermo-Sifiliográficas. 2015; 106:68-9. 